\title{
Four new threatened species of Rinorea (Violaceae), treelets from the forests of Cameroon
}

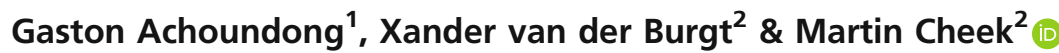

Summary. Four species of Rinorea are described as new to science; all four species are endemic to evergreen rain forest in Cameroon. Rinorea villiersii Achound. and R. amietii Achound are placed in Rinorea [unranked] Crassiflorae M.Brandt, while, $R$. dewildei Achound. and $R$. faurei Achound. fall in Rinorea [unranked] Dentatae Engl. The first species appears to be endemic to the Solé Forest Reserve northeast of Yabassi in Littoral Region. The second and the third species are found mainly in Littoral and South Regions, R. amietii extending to South West Region and $R$. dewildei extending to Central Region. The fourth species, $R$. faurei is an endemic of the Santchou Forest Reserve at the foot of Dschang Plateau in West Region. The taxonomic affinities of the four species are discussed, illustrations and a distribution map are provided, and their conservation status is assessed. All four species are threatened with extinction according to the 2012 IUCN categories and criteria.

Key Words. Butterflies, conservation, Cymothoe, staminal tube.

\section{Introduction}

In the course of revising the species of Violaceae of Africa, mainly in preparation for the account of the Violaceae for the Flore du Cameroun, the first author has, with various collaborators, already published 13 new species to science for this group (Achoundong \& Onana 1998; Achoundong \& Bos 1999; Achoundong \& Bos 2001; Achoundong 2003; Achoundong \& Cheek 2003; Achoundong \& Cheek 2005; Achoundong \& Bakker 2006). Other publications have used provisional names which are now used for the new species published here (Achoundong 1996; Achoundong 1997; Amiet \& Achoundong 1996; Achoundong 2000; Bakker et al. 2006). In this paper, four such provisional species names are formally published to validate these names.

The most recent studies of the phylogeny and classification of African Rinorea Aubl. are set out by Wahlert (2010), Wahlert \& Ballard (2012) and van Velzen et al. (2015). However, the classification of Brandt (1914) has still not been formally replaced. The first two new species described below, $R$. villiersii Achound. and $R$. amietii Achound. fall within Rinorea [unranked] Crassiflorae M.Brandt, while the second two species, $R$. dewildei Achound. and $R$. faurei Achound. fall in Rinorea [unranked] Dentatae Engl.

The genus Rinorea is pantropical, with 206 species currently accepted by Plants of the World Online, (continuously updated), accessed April 2021). Africa is the most species-diverse continent for Rinorea with 110
- 150 species (van Velzen et al. 2015). Rinorea species are mainly forest understorey shrubs or small trees. Morphologically, in continental Africa, they are characterised by having alternate, simple leaves, often with petioles of different lengths on the same stem and an usually long, curving apical bud (in the Neotropics and Madagascar, some species e.g. Rinorea sect. Pubiflora Wahlert \& H.E.Ballard have opposite leaves). The flowers are often green, dull yellow, or shades of white and are zygomorphic. There are three sets of petals in Rinorea: an anterior petal (also known as the lower or ventral petal), two lateral petals and two posterior petals. These are likely homologous to the three sets of petals in other strongly zygomorphic genera of Violaceae, such as Viola L. (Wahlert 2010).

The anterior petal is larger than the other petals, and often modified, with taxonomically important, often diagnostic characters. The androecium has a staminal tube which is also zygomorphic: the anterior (lower or ventral) side is longer and entire, while on the dorsal side of many of the African species, the staminal tube is generally shorter and incised with a Vshaped cleft. The fruits are typical of the family: dry, tricoccal, septicidal capsules with parietal placentation.

Rinorea are ecologically important and diverse in African forests, often with several sympatric species in one forest. For example, ten species were recorded in a few square kilometres of the Mefou Proposed National Park near Yaoundé (Achoundong in Cheek et al. 2011). Many species are range-restricted, found

\footnotetext{
Accepted for publication 20 September 2021. Published online 8 November 2021

1 IRAD-Cameroon National Herbarium, BP 1601, Yaoundé, Cameroon.

2 Herbarium, Royal Botanic Gardens, Kew, Richmond, Surrey, TW9 3AE, UK. e-mail: m.cheek@kew.org
} 
in such small areas that they are at risk of extinction from forest clearance. Rinorea dewitii Achound., $R$. fausteana Achound., R. simoneae Achound. and $R$. thomasii Achound. are all assessed as threatened in the Red Data Book of the Flowering Plants of Cameroon (Onana \& Cheek 2011) and all but the first can be found on the IUCN Red List (iucnredlist.org) e.g., R. thomasii (Darbyshire \& Cheek 2004a; Cheek 2017; Darbyshire \& Cheek 2004b). In neighbouring Gabon, the recently published $R$. calcicola Velzen \& Wieringa is also range-restricted and of conservation concern (van Velzen \& Wieringa 2014). Cameroon has the highest species-diversity for the genus in tropical Africa with 53 species listed (Onana 2011), followed by Gabon, with 46 species (Sosef et al. 2006). However, the superficial similarity between species has made identification difficult for taxonomists, e.g., 194 specimens of Rinorea are listed as unidentified to species for Gabon in Sosef et al. (2006).

African Rinorea species are of great interest to entomologists, being important larval food plants of the butterfly genus Cymothoe (the gliders). Twentyeight species of Cymothoe are known to feed on Rinorea, of which 18 are strictly monophagous, six are oligophagous and three feed on up to six species of Rinorea (Amiet \& Achoundong 1996).

\section{Materials \& Methods}

All specimens cited have been seen. Herbarium citations follow Index Herbariorum (Thiers, continuously updated). Specimens were studied online, on loan from or at BR, K, P, WAG and YA. We also searched JSTOR Global Plants (https://plants.jstor.org/ accessed April 2021) for additional materials. Taxonomic authorities follow the International Plant Names Index, (IPNI continuously updated), and nomenclature follows Turland et al. (2018). The conservation assessments were made using Bachman et al. (2011) following the categories and criteria of IUCN (2012). Herbarium material was examined with a Leica Wild M8 dissecting binocular microscope fitted with an eyepiece graticule. Measurements were made from rehydrated material. The terms and format of the description follow the conventions of Achoundong \& Cheek (2005). Post-facto georeferences for specimens without coordinates were obtained from Google Earth.

(https://www.google.com/intl/en_uk/earth/versions/).

\section{Taxonomic Treatment}

1. Rinorea villiersii Achound. sp. nov. Type: Cameroon, Littoral Region, Sole, north-west of Yabassi, fl. 20 May 1992, Achoundong 1928 (holotype YA; isotypes, P, WAG).

http://www.ipni.org/urn:lsid:ipni.org:names:77220452-1

Rinorea villiersii Achound. ined. (Achoundong 1996, 1997; Onana 2011: 151).

Rinorea solensis Achound. ined. (Achoundong 1996, 1997).

Evergreen shrub or treelet 1 - 2 (- 3) $\mathrm{m}$ tall, densely branched. Stems and leaves pubescent when young, glabrous at maturity. Leaves white when young, subcoriaceous, elliptic, $11-20(-22) \times 3-5(-7) \mathrm{cm}$ strongly long acuminate, base cuneate, margin serrate; lateral nerves $10-13$ on each side of the midrib. Petiole $1.5-2(-3) \mathrm{cm}$ long. Stipules triangular, $2-3$ $(-4) \times 0.5-1$ (- 2) $\mathrm{mm}$, mucronate, with two prominent longitudinal nerves, margins crenate, ciliate. Inflorescence terminal, corymbiform, $2.5-3.5(-5)$ $\times 1.5-2(-3) \mathrm{cm}$. Bracts $5-6$, triangular, $3-4(-5) \times$ $1-2$ (-3) mm, mucronate, ciliolate, pubescent. Flowers zygomorphic, $3-4(-5) \times 2-3(-4) \mathrm{mm}$; sepals 5, green, triangular, $(1-2(-3) \times 0.5-1(-1.5)$ $\mathrm{mm}$ ciliolate. Petals 5, white, ovate, $4-5(-6) \times 1-1.5$ (- 2) $\mathrm{mm}$; anterior (large) petal broader than the posterior (upper) and the lateral petals, constricted towards the apex, inner surface densely hairy towards the apex. Androecium 3-4 mm long; staminal tube $0.5-1(-1.5) \mathrm{mm}$ long, margin entire, undulate, with a V-shaped incision in the dorsal face; filaments short, inserted on the inner face of staminal tube; staminal tube border hiding the lower part of anthers, anthers 0.5 - 1 (- 1.5) mm long; connective appendage red, ovate, up to $0.5-1(-1.5) \mathrm{mm}$ long, thecal appendages filiform, bifid. Ovary fusiform, hairy, $1-1.5(-2) \mathrm{mm}$ long; style erect, $1-1.5$ (- 2) mm long. Fruit white, tricoccal, fusiform $1-1.5(-2) \times 1-1.5 \mathrm{~cm}$, tuberculate. Seeds six per fruit, white, tetrahedral. Fig. 1.

RECOGNITION. Rinorea villiersii Achound. is similar to R. umbricola Engl., in habit, the long sepals, and the large androecium. It differs in the white juvenile leaves (vs green), the leaves long-acuminate with cuneate bases, pubescent, lacking gland dots on the lower surface (vs acuminate, cordate, glabrous, with gland dots on the lower surface), the ovary fusiform, pubescent (not ovoid, glabrous). The two species can be separated by the following key characters:

Lamina $10-12 \times 3.5-4.5 \mathrm{~cm}$, glandular beneath; ovary glabrous . . . . . . . . . . . Rinorea umbricola Lamina $11-22 \times 3-7 \mathrm{~cm}$, not glandular beneath; ovary pubescent $\ldots \ldots \ldots \ldots$. . . . Rinorea villiersii 

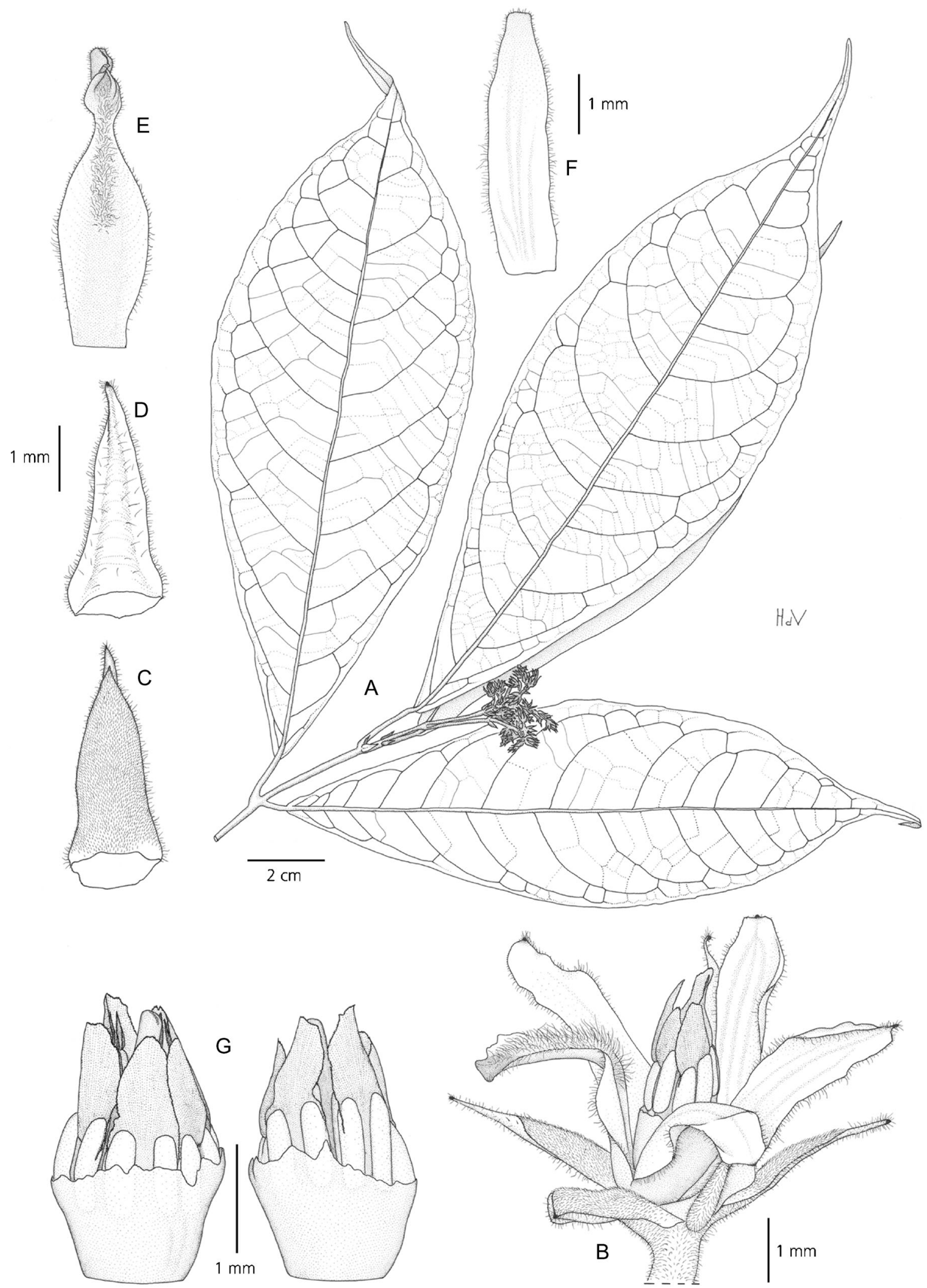

Fig. 1. Rinorea villiersii. A habit, flowering stem; B flower, side view; C sepal adaxial view; D sepal abaxial view; E anterior (large) petal, adaxial view; $\mathrm{F}$ one of the four smaller posterior and lateral petals, adaxial view; $\mathrm{G}$ staminal tube, side views. A \& B from Achoundong 2212 (WAG); C - G from Achoundong 1928 (WAG). DRAWN BY J. M. (HANS) DE VRIES. 
DISTRIBUTION. Cameroon. Rinorea villiersii is endemic to the Solé Forest, Solé-Dibong area, north west of Yabassi town, Littoral Region (Map 1).

SPECIMENS STUDIED. CAMEROON. Littoral Region, Solé, Yabassi area, fl., 15 March 1991, Amiet in Achoundong 1792 (P, YA); ibid., fl. 20 May 1992, Achoundong 1928 (holotype YA; isotypes P, WAG); ibid., fl. fr., May 1994, Achoundong 2212 (WAG, YA); Yabassi area, river bank in Solé Forest Reserve, fl., 9 May 2004, Achoundong 2328 (YA).

HABITAT. Rinorea villiersii is known from lowland evergreen rain forest in the Solé-Dibong area northwest of Yabassi. The relief in its range is undulating, with valleys and plains. All specimens were collected from the borders of a river, at altitudes from 20 to $100 \mathrm{~m}$.

CONSERVATION STATUS. Rinorea villiersii is only known from the Solé Forest Reserve. Based on current evidence and the observations of the first author, we estimate the total extent of occurrence of $R$. villiersii, equating to the global area of occupation, as $20 \mathrm{~km}^{2}$. This forest currently has good conservation status in that much of it is intact (Google Earth imagery viewed 11 April 2021) but there are no concrete conservation actions in place. The area has a low human population density. Unfortunately, it is only $14 \mathrm{~km}$ along a major road from the settlement of Loum which is a highly populated area with active farmers. They are expected in the future to invade the reserve for farming purposes, resulting in major threats to this species.

Botanical surveys and other plant studies for conservation management in forest areas north, west and east of Solé Forest Reserve have resulted in many thousands of specimens being collected and identified, but failed to find any additional specimens of R. villiersii (Cable \& Cheek 1998; Cheek et al. 2000; Maisels et al. 2000; Chapman \& Chapman 2001; Harvey et al. 2004; Cheek et al. 2004; Cheek et al. 2010; Harvey et al. 2010; Cheek et al. 2011). Although there are still poorly sampled locations with intact natural habitat in Cameroon, it is possible that $R$. villiersii is truly localised, range-restricted and threatened as are several other species of the genus (see introduction). Rinorea villiersii is therefore here assessed, on the basis of the single location, small known range-size and threats described above, as Critically Endangered, CR B1+2ab(iii).

ETYMOLOGY. The specific epithet commemorates the late Dr Jean François Villiers (1943 - 2001), taxonomic specialist in mimosoid Leguminosae (also known as Mimosaceae) of Africa and Madagascar, staff member of the Herbarium at MNHN, Paris and lecturer at the University of Yaoundé. He was the supervisor of the first author's doctoral thesis on
Rinorea. He did much to encourage botanists in Cameroon to study conservation.

VERNACULAR NAMES \& USES. None are recorded.

2. Rinorea amietii Achound. sp. nov. Type: Cameroon, Littoral Region, Marienberg, March 1992, fl. Achoundong 1853 (holotype P; isotypes WAG, YA).

http://www.ipni.org/urn:lsid:ipni.org:names:77220453-1

Rinorea amietii ined. Achoundong (1996: 544); Amiet \& Achoundong (1996: 465); Achoundong (1997); Onana (2011: 150).

Shrub or small tree $5-7(-8) \mathrm{m}$ high. Diameter of the trunk at $1.3 \mathrm{~m}$ above the ground up to $10 \mathrm{~cm}$. Stems and leaves ferruginously hairy, most densely pubescent when young. Leaves subcoriaceous, elliptic, 9 $17(-20) \times 3-7(-9) \mathrm{cm}$, broadly acuminate, base cuneate, margin serrate, lateral nerves $12-13$ on each side of the midrib. Petiole $5-3(-4) \mathrm{cm}$ long. Stipules triangular, $2-5 \times 1-1.5 \mathrm{~mm}$, mucronate, densely pubescent. Inflorescences terminal or subterminal, pubescent, corymbiform, $1.5-5(-6) \times 1.5-$ $2.5(-4) \mathrm{cm}$, bracts triangular $3-5(-6) \times 1-1.5(-$ 2) $\mathrm{mm}$, pubescent, densely so on the midrib, apiculate. Flower zygomorphic, $4-5(-6) \times 3-4$ mm. Sepals 5, bright yellow, oblong $1.5-2.5(-3) \times$ $0.5-1.5(-2) \mathrm{mm}$, pubescent. Petals 5 , yellow, ovate to elliptic, $2-4(-5) \times 1-1.5(-2) \mathrm{mm}$, narrowed at the base, apex rounded, ciliate. Anterior (lower) petal enlarged at the middle, narrowed at the extremities, more strongly near the apex; hairy at the apex of the inner face, lateral and posterior petals oblong, smaller. Androecium 2.5 - $3.5(-4) \mathrm{mm}$ long; staminal tube up to $1-1.5$ (- 2) $\mathrm{mm}$ high; margin free, undulate, with a $\mathrm{V}$-shaped incision in dorsal face; filaments all inserted on the inner face of the staminal tube; anthers $0.5-1.5(-2) \mathrm{mm}$ long; connective appendage red, ovate $1-1.5(-2) \mathrm{mm}$ long, thecal appendages bifid, filiform. Ovary bottleshaped, $0.5-1(-1.5) \mathrm{mm}$ long, glabrous; style erect, $1.2-2(-2.5) \mathrm{mm}$ long, enlarged at the summit, with longitudinal furrows. Fruit ovoid, $2 \times 1.5 \mathrm{~cm}$, surface white, slightly tuberculate. Seeds six, black, angular, dorsal faces convex, inner faces planar. Fig. 2.

RECOGNITION. In its habit, its ferruginous leaves and its very short apical stem bud, Rinorea amietii is morphologically (but not phylogenetically) close to $R$. subsessilis M.Brandt, but differs in the leaves being pubescent and non-glandular below (vs glabrous and glandular), the petal midrib pubescent (not glabrous), and in additional features in the key below. The two species are separated by the following characters: 


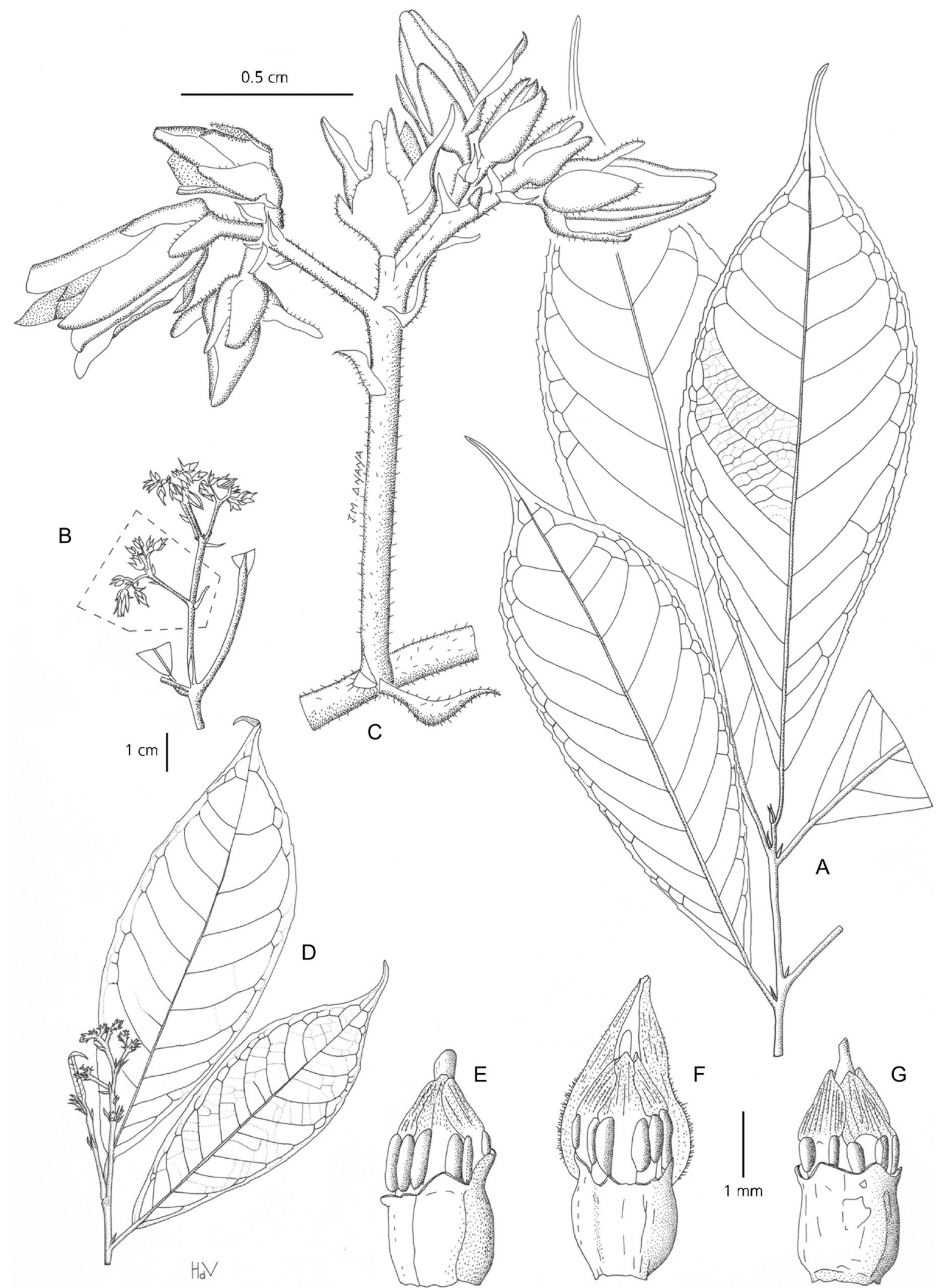

Fig. 2. Rinorea amietii. A habit, sterile leafy shoot; $B$ habit showing position of terminal inflorescence; $C$ detail of $B$ showing portion of inflorescence; D habit, stem with inflorescence and buds; E - G views of staminal tube. A - C \& E - G from Achoundong 1744 (YA); D from Achoundong 1853 (WAG). A - C \& E - G DRAWN BY JEAN MICHEL ONANA, D BY J. M. (HANS) DE VRIES. 
Lamina glabrous, glandular below, fruit green, smooth, inflorescence glabrous, $3-15 \mathrm{~cm}$ long, sepals glabrous,

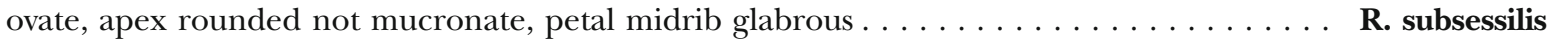
Lamina pubescent, not glandular below, fruit white, verrucose, inflorescence pubescent, $2-5 \mathrm{~cm}$ long, sepals densely pubescent, triangular to trapezoid, acute at the summit, mucronate, petal midrib

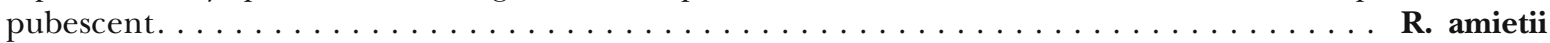

DISTRIBUTION. Cameroon. Rinorea amietii is endemic to coastal (littoral) Cameroon in the South West Region, Littoral Region and South Region (Map 1).

SPECIMENS STUDIED. CAMEROON. South West Region, Ekumbe Mufako, fl., May 1994, Ndam 1198 (K, SCA, YA); Ekumbe Mufako, fl., May 1994, Sonké 1217 (K, SCA, YA); Ekumbe Mufako, fl., May 1994, Thomas 10121 (K, SCA, YA); Littoral Region, Dizangue area, Ossa Lake, fl. 5 April 1984, Achoundong 944 (P, YA); km 30, Edéa-Douala road, fl. 13 Jan. 1990, Achoundong 1550 (P, YA); Mangonbe border, fl. 2 March 1990, Achoundong 1627 (K, P, YA); $30 \mathrm{~km}$ on Edéa-Douala road, fl., fr., 28 July 1990, Achoundong 1744 (WAG, YA); Bonépoupa, $30 \mathrm{~km}$ on Edéa-Douala road, fl. 22 May 1991, Achoundong 1824 (P, YA); km 30 EdéaBonépoupa road, fl. 22 May 1991, fl., fr. Achoundong 1836 (P, YA); Mangonbé border, Edéa-Songloulou road, 22 May 1991, fl. Achoundong 1839 (YA); Littoral Region, Marienberg, March 1992, fl. Achoundong 1853 (holotype P; isotype, K); region de Mouanko, fl. March 1992, Achoundong 1864 (YA); Edéa-Douala road 19 Feb. 2001, Achoundong 2106 (YA); 20 km from Douala on Edéa road, Carriere Ducam Duclair, 20 Dec. 2002, Achoundong 2198 (YA); 25 km NW of Edéa, SW of "Carrière Ducam Duclair", forest at field of Marcel Melingui Engama $3^{\circ} 55.01$ 'N, $10^{\circ} 03.30 ' \mathrm{E}$, fr. 5 May 2006, van Velzen 50 (WAG041636); South Region Kribi area, Bidou I, fl. March 1993, Achoundong 2011 (YA); Bipindi area, Nsola, fl., March 1993, Achoundong 2020 bis (YA); Bipindi area, Nsola, fl., June 1994, Achoundong 2204 (YA); $20 \mathrm{~km}$ from Kribi on Lolodorf road, fr. 7 Aug. 1969, Bos 5154 (K, WAG); 20 km from Kribi, 3 km $\mathrm{N}$ of Lolodorf road, fr. 18 July 1969, Bos 5101 (K, WAG); Bipindi, fl., 1896, Zenker 1078 (K); Bipindi, fl. 1896, Zenker 1079 (K, P); Bipindi, fl. 1904, Zenker 2680 (BM, K).

HABITAT. Rinorea amietii is known from littoral lowland evergreen rain forests. The altitude ranges from 0 to $300 \mathrm{~m}$. CONSERVATION STATUS. The littoral lowland evergreen rain forests of Cameroon are rich in Rinorea species. Many of the species are narrow endemics and so are vulnerable to extinction from forest clearance. Littoral forest habitat is highly threatened due to its ability to host industrial agriculture and because it is a target for logging activity. Many industrial farms are already located there, cultivating crops such as banana (Musa spp.), palm oil (Elaeis guineensis), and rubber (Hevea brasiliensis). Due to its proximity to the coastal ports and the density of roads, littoral forest habitat is in demand for clearance for the expansion of these industries.

Currently eight locations are recorded for Rinorea amietii based on the 23 specimens studied, following extensive surveys in Cameroon detailed above under $R$. villiersii). The extent of occurrence is estimated as $9,545 \mathrm{~km}^{2}$, and the area of occupation as $60 \mathrm{~km}^{2}$. Given the threats above, we assess $R$. amietii as Vulnerable VU B1+2ab(iii).

ETYMOLOGY. The specific epithet commemorates Professor Jean-Louis Amiet, lecturer at University of Yaoundé. He studied the relationship between butterflies and plants, especially that between Cymothoe (the gliders with about 75 species in Africa) and the genus Rinorea (Amiet 1997; Amiet 2000), and inspired the first author in his life's taxonomic research on the genus Rinorea in Africa (Amiet \& Achoundong 1996). He is commemorated by several other species such as Afrothismia amietii Cheek (Thismiaceae, Cheek 2007). Amiet, an entomologist, came to understand in the 1980s that the Cymothoe butterflies he studied were often monophagous, the larvae of some species eating only one species of Rinorea (see Introduction). However, at that point, these different species of Rinorea were not recognised by taxonomists because of the superficial similarity of many other species. To address this difficulty he recruited the first author!

NOTES. Recent data from the chloroplast marker trnL$\mathrm{F}$ and the nuclear ribosomal ITS, indicate that Rinorea amietii is related to $R$. longisepala Engl., $R$. ledermannii Engl. and $R$. umbricola Engl. (Robin van Velzen pers. comm. to Achoundong, June 2021) supporting placement in Rinorea [unranked] Crassiflorae.

3. Rinorea dewildei Achound., sp. nov. Type: Cameroon, Central Region, 35 km NW d' Eséka, fl. 23 March 1964, W. J.J. O. de Wilde 2218 (holotype WAG; isotypes K001381925, P, YA).

http:/ /www.ipni.org/urn:lsid:ipni.org:names:77220455-1

Rinorea dewildei ined. Achoundong (1996: 544), Amiet \& Achoundong (1996: 310); Onana (2011: 150).

Shrub or treelet up to $5 \mathrm{~m}$ high. Young twigs puberulent. Leaves papery, lamina elliptic, $7-18 \times 2-7 \mathrm{~cm}$, apex broadly acuminate, base cuneate to obtuse, margin serrate, lateral nerves $6-8$ pairs, $3-4$ of which are more prominent than the others. Stipules triangular 6 $\times 2 \mathrm{~mm}$, mucronate, abaxial midrib pronounced, pubescent, margin ciliolate. Petiole 5 - $15 \mathrm{~mm}$ long, pubescent. Inflorescence terminal, glabrous, corymbose, $3.5-4 \mathrm{~cm}$. long; bracts triangular, up to $1 \times 1.5 \mathrm{~mm}$, 
ciliolate. Flowers yellow, $4 \times 2 \mathrm{~mm}$; sepals yellow, triangular, $2.5 \times 1.2 \mathrm{~mm}$, ciliolate. Petals yellow, anterior (lower petal) ovate, $4 \times 1 \mathrm{~mm}$, ciliolate; 3nerved; posterior and lateral petals oblong, $3 \times 1 \mathrm{~mm}$, apex truncate-retuse, 1-nerved. Androecium $2-3 \mathrm{~mm}$ long; staminal tube urceolate, $1.5 \mathrm{~mm}$ long; margin free, undulate, with a dorsal slit; staminal filaments inserted on the inner face of the staminal tube; filament of the dorsal stamen inserted near the distal edge of the staminal tube, on the dorsal slit; anthers $0.5 \mathrm{~mm}$ long; connective appendage red, ovate $0.5-1 \mathrm{~mm}$ long; thecal appendage bifid. Ovary ovoid, glabrous, $1 \mathrm{~mm}$ long; style
$2 \mathrm{~mm}$ long, expanded at the summit. Fruit white, ovoid, tuberculate, $1.5(-2) \times 1(-1.5) \mathrm{cm}$. Seeds tetrahedral, 0.5 $\times 0.5 \mathrm{~cm}$. Fig. 3 .

RECOGNITION. In Rinorea dewildei the lamina is distinctive in that $3-4$ of the lateral nerves are more prominent than the others. Rinorea cerasifolia M.Brandt shows the same character. Rinorea dewildei has petioles $0.5-1.5 \mathrm{~cm}$ long, sepals twice as long as broad (vs to $5 \mathrm{~cm}$ long, sepals as long as broad in $R$. cerasifolia). The species are further distinguished as follows:

Petiole up to $5 \mathrm{~cm}$ long, tertiary venation of lamina sparse and inconspicuous; sepals ovate, as long as broad; all staminal filaments inserted on the inner face of the staminal tube . . . . . . . . . Rinorea cerasifolia Petiole $0.5-1.5 \mathrm{~cm}$ long; tertiary venation of lamina dense and prominent; sepals triangular, twice as long as broad; one of the staminal filaments inserted on the slit of staminal tube margin, the others on the inner face $\ldots \ldots \ldots \ldots \ldots \ldots \ldots \ldots \ldots \ldots \ldots \ldots \ldots \ldots \ldots$ Rinorea dewildei

DISTRIBUTION. Cameroon. Rinorea dewildei is found in the Central Region, Littoral Region and South Region (Map 1).

SPECIMENS STUDIED. CAMEROON. Littoral Region, border of Nyong river at Dehane, fl., 1 March 1990, Achoundong 1623 (K, P, YA); ibid., Achoundong 2105 (YA); "Carriere Ducam Duclair", 20 km N of EdéaDouala road, fl., 20 Feb. 2002, Achoundong 2197 (YA); 12 km Edéa road, fl., 23 March 1994, Achoundong 2339 ED (P, YA); Edéa area, fl., May 1994 Achoundong 17 ED (YA); Central Region, Makak, littoral forest, $100 \mathrm{~km} \mathrm{~W}$ of Yaoundé, young fr. Oct. 1938, Jacques-Felix 2288, (P); 35 km NW of Eséka, 23 March 1964, W. J. J. O. de Wilde 2218 (holotype WAG; isotypes K, P, YA). $6 \mathrm{~km} \mathrm{NE}$ of Edéa, forest at Eding Island, $3^{\circ} 48.97^{\prime} \mathrm{N}, 10^{\circ} 08.17^{\prime} \mathrm{E}$, imm. fr., 7 May 2006, van Velzen 43 (WAG0416447). South Region. Bibabimvoto, Dipikar Island, in the Campo area along transect T2; fr., 19 July 2000, Tchouto T2X195 (WAG); Mabiogo, Dipikar island, in the Campo area along transect T1, fr., 20 Sept. 2000, Tchouto T1X144 (WAG); Bimbabivoto, Forest along transect T2 in Campo Maan area, fr., 18 July 2000, Tchouto 2951 (WAG).

HABITAT. Rinorea dewildei occurs in littoral lowland evergreen rainforest. The altitude ranges from 0 to $700 \mathrm{~m}$. This species appears common in many areas of Cameroonian littoral forest but despite this has surprisingly few collections.

CONSERVATION STATUS. According to Tchouto, Rinorea dewilde $i$ is common in the Campo-Ma'an National Park. Consequently, the species is well protected within the park. However, at locations outside the park, such as at Makak, Edéa and Eséka, the habitat of this species is being cleared for agriculture and urbanisation.

Currently, after extensive surveys in Cameroon (see under Rinorea villiersii), six locations are recorded for
R. dewildei (see specimens above), the extent of occurrence is estimated as $12,430 \mathrm{~km}^{2}$, and the area of occupation as $36 \mathrm{~km}^{2}$. Given the threats above, we assess $R$. dewildei as VU B1+2ab(iii).

ETYMOLOGY. The specific epithet commemorates Dr W.J. J. O. de Wilde. He and his wife, Brigitte de Wilde-Duyfjes collected the type specimen. Together, from their base at N'Kolbisson in Yaoundé in the 1960s, they collected numerous excellent botanical herbarium specimens in large sets through many parts of Cameroon, including the littoral areas where Rinorea dewildei still grows. At this time their home institution, Herbarium Vadense (WAG), then at Wageningen, Netherlands, was highly active in conducting botanical surveys in poorly studied but speciesrich areas of tropical Africa, such as Cameroon and Gabon. Sixty years later, we are still naming species new to science resulting from their efforts, such as this.

NOTES. One anomalous specimen from Gabon (MoyenOgooué, Camp Mboumi base, river bank, fr., fl. 20 Aug. 1999, Issembe 191 (K, LBV, WAG), shares many similarities with Rinorea dewildei, and was initially identified as this species, but is here excluded. It may represent a further undescribed new species to science.

4. Rinorea faurei Achound. sp. nov. Type: Cameroon, West Region, Santchou Forest Reserve, fl. Achoundong 1936 (holotype YA, isotypes P, WAG).

http:/ / www.ipni.org/urn:lsid:ipni.org:names:77220456-1

Rinorea faurei ined. Achoundong (1996: 544), Achoundong (1997: 255); Onana (2011: 150).

Shrub or treelet $1.5-2.5(-5) \mathrm{m}$ high, stems and leaves glabrous. Leaves sub-coriaceous, elliptic to slightly 

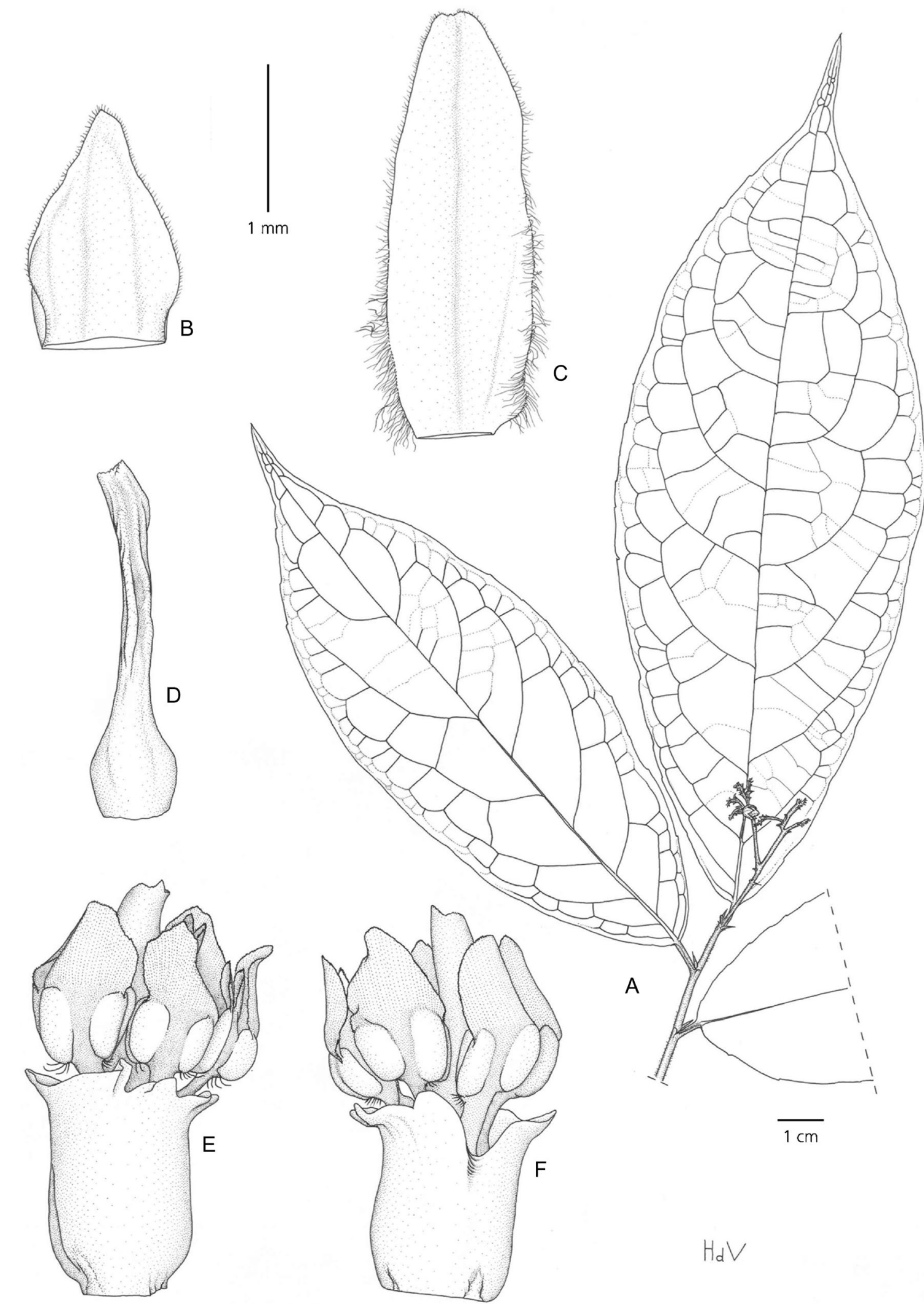

$H_{d} V$

Fig. 3. Rinorea dewildei. A habit, flowering stem; B sepal; C petal; D pistil; E \& F staminal tube, side views. All from W. J. J. O. de Wilde \& B. E. E. de Wilde-Duyfjes 2218 (WAG). DRAWN BY J. M. (HANS) DE VRIES. 
ovate, $12-21 \times 4.5-6(-9.5) \mathrm{cm}$, acuminate, base cuneate to obtuse, margin slightly serrate to subentire; lateral nerves $8-12$ on each side of the midrib. Petiole $1-2.5(-5) \mathrm{cm}$ long. Stipules triangular, $6 \times 2$ $\mathrm{mm}$, mucronate, midrib abaxially pubescent, margin ciliolate. Inflorescences terminal or subterminal, thyrsiform, glabrous c. $4 \times 1.5 \mathrm{~cm}$; bracts triangular, $1 \times 1.5 \mathrm{~mm}$, apiculate, abaxial midrib and margin ciliolate. Flowers white, zygomorphic, 4.5 - $6 \mathrm{~mm}$ long. Sepals 5, green, triangular to elliptic $1-1.3 \times 1-1.5$ $\mathrm{mm}$. Petals white to yellow, elliptic, flat, $1.5-3 \times 1-$ $1.5 \mathrm{~mm}$, apex rounded, margin ciliate. Anterior (lower) petal broader than the posterior (upper) and lateral petals, slightly constricted towards the apex, inner surface hairy near the apex. Androecium $3 \mathrm{~mm}$ long, staminal tube $0.3-1 \mathrm{~mm}$ long, margin free, with a V-shaped dorsal incision; filaments inserted on the inner face of the tube; anthers of the ventral side (face), fully exserted from the tube with free space between the tube summit and the lower part of the anthers; anthers 5, each $1 \mathrm{~mm}$ long, connective appendage red, ovate, $1-1.3 \mathrm{~mm}$ long, apex rounded, base decurrent on the upper part of the anthers. Ovary 3-locular, yellow, pyriform, $7 \times 1 \mathrm{~mm}$, style straight, cylindrical, white, $2 \mathrm{~mm}$ long, slightly constricted at the apex, stigma capitate. Fruit white, broader than long, $2 \times 3 \mathrm{~cm}$, strongly 3-lobed. Seeds six, white, acutely angled, dorsal face convex, ventral face flat c. $5 \times 5 \mathrm{~mm}$. Fig. 4 .

RECOGNITION. In its habit and its thyrsoid inflorescence Rinorea faurei is close to two other Rinorea species of the forest understory: $R$. sinuata Chipp and $R$. thomasii, differing from the first in having the flowers dispersed in an elongated, lax cyme (vs a dome-shaped, compact cyme), differing from the second in the leaves elliptic, ovate or obovate and long-acuminate (vs oblong and shortly acuminate):

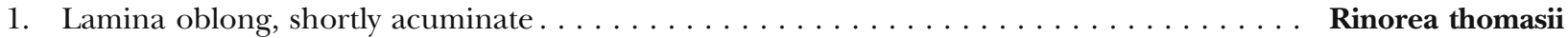

1. Lamina elliptic or ovate to obovate, long-acuminate $\ldots \ldots \ldots \ldots \ldots \ldots$

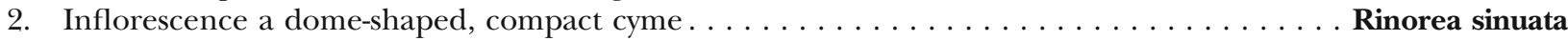

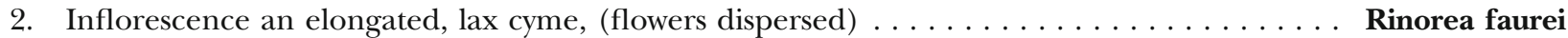

DISTRIBUTION. Cameroon. Rinorea faurei is endemic to the Santchou area in West Region (Map 1).

SPECIMENS STUDIED. CAMEROON. West Region. Santchou Forest Reserve, fl., 17 March 1991, Achoundong 1786 (P, WAG, YA); ibid., fl., fr. 19 May 1992, Achoundong 1925 (YA); ibid., Achoundong 1936 (holotype YA; isotypes P, WAG).

HABITAT. Rinorea faurei occurs in understory of evergreen rain forest in the Santchou Plain at the foot of the Dschang Plateau. The estimated elevation above sea level is $770 \mathrm{~m}$. The area of forest is more than 7000 ha. Santchou Forest Reserve is also the home of $R$. dentata Kuntze, $R$. oblongifolia C.Marquand, $R$. yaundensis Engl. and $R$. batesii Chipp (Achoundong pers. obs. 1991 - 1992).

CONSERVATION STATUS. Santchou Forest Reserve has official protection status. However, lack of concrete action on the ground means a strong risk of the reserve being invaded by farmers since the Santchou Plain is intensively cultivated.

Currently, after extensive surveys in Cameroon (see under Rinorea villiersii above), only a single location in the sense of IUCN (2012) is recorded for R. faurei (see specimens above), the extent of occurrence and the area of occupation is estimated as $70 \mathrm{~km}^{2}$. Given the threats above, we assess $R$. faurei as Critically Endangered, CR B1+2ab(iii).

ETYMOLOGY. The specific epithet honours JeanJacques Faure, former Head of the Forestry High School in Cameroon. His contribution to the protec- tion of the environment of Central Africa has been important.

\section{Discussion}

More collections of Rinorea in Cameroon are needed. The more widespread species such as $R$. dewildei (see note there) have surprisingly few collections, even though the first author has noted they can be quite common within their range. It appears that many collectors avoid targeting the genus in their botanical inventory work, perhaps doubting that one species differs from another and seeking to avoid duplicating collections of the same taxon. The first author, in contrast, targeted the genus in his field surveys, accounting for his collections being the majority of those cited in this paper. This demonstrates how under-collected these Cameroon littoral forests are generally and confirms that more herbarium specimens should be collected to determine which species are present in these forests before they are lost.

About 2000 species of vascular plant have been described as new to science each year for the last decade or more. Until species are known to science, they cannot be assessed for their conservation status and the possibility of protecting them is reduced (Cheek et al. 2020). To maximise the survival prospects of range-restricted species there is an urgent need not only to document them formally in compliance with the requirements of 


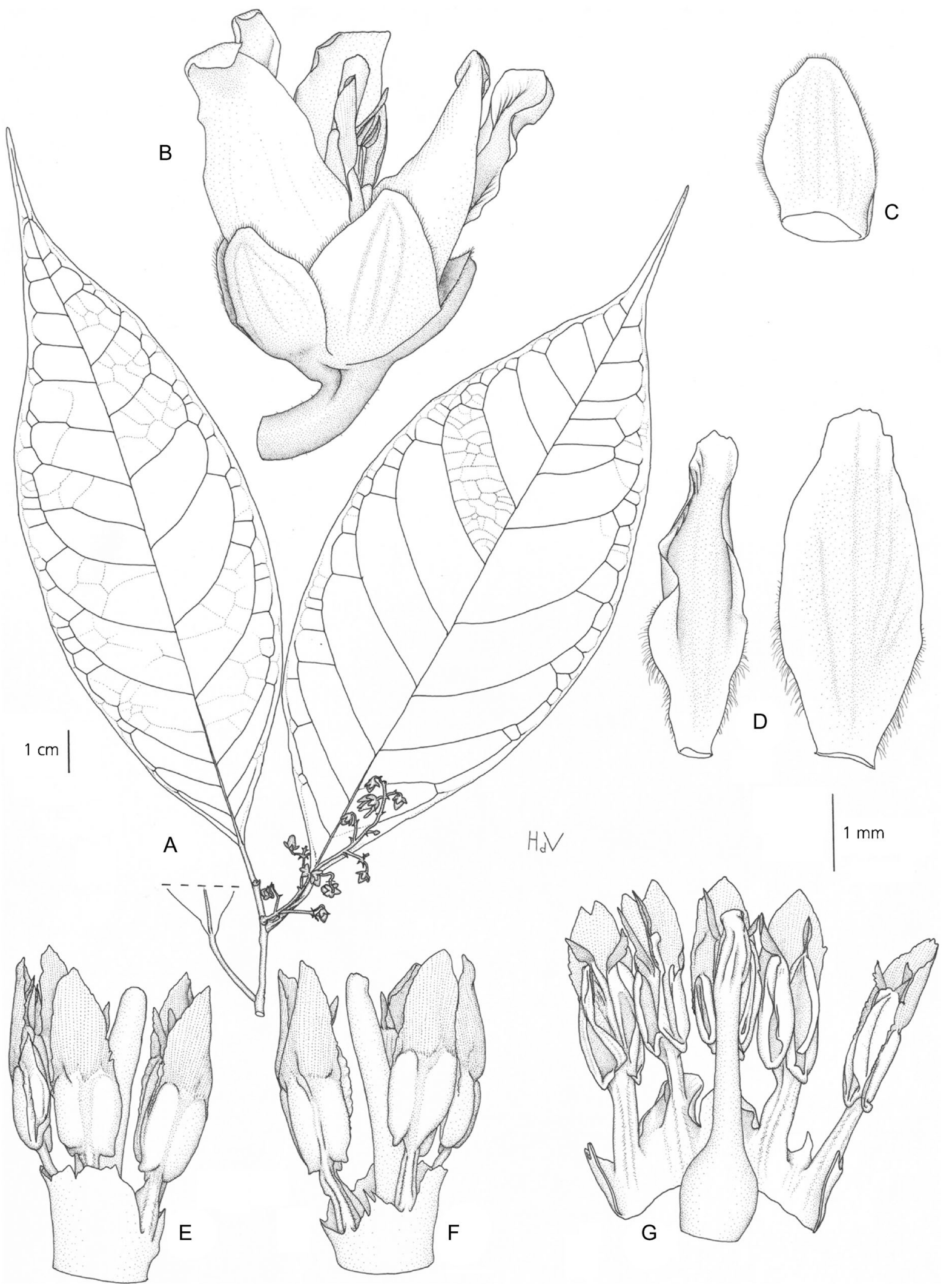

Fig. 4. Rinorea faurei. A habit, flowering stem; B flower, side view; $C$ sepal; D petals, large (left) and small (right); E \& F staminal tube and pistil, side views; G staminal tube and pistil, opened to show inner surface. All from Achoundong 1936 (WAG). DRAWN BY J. M. (HANS) DE VRIES. 


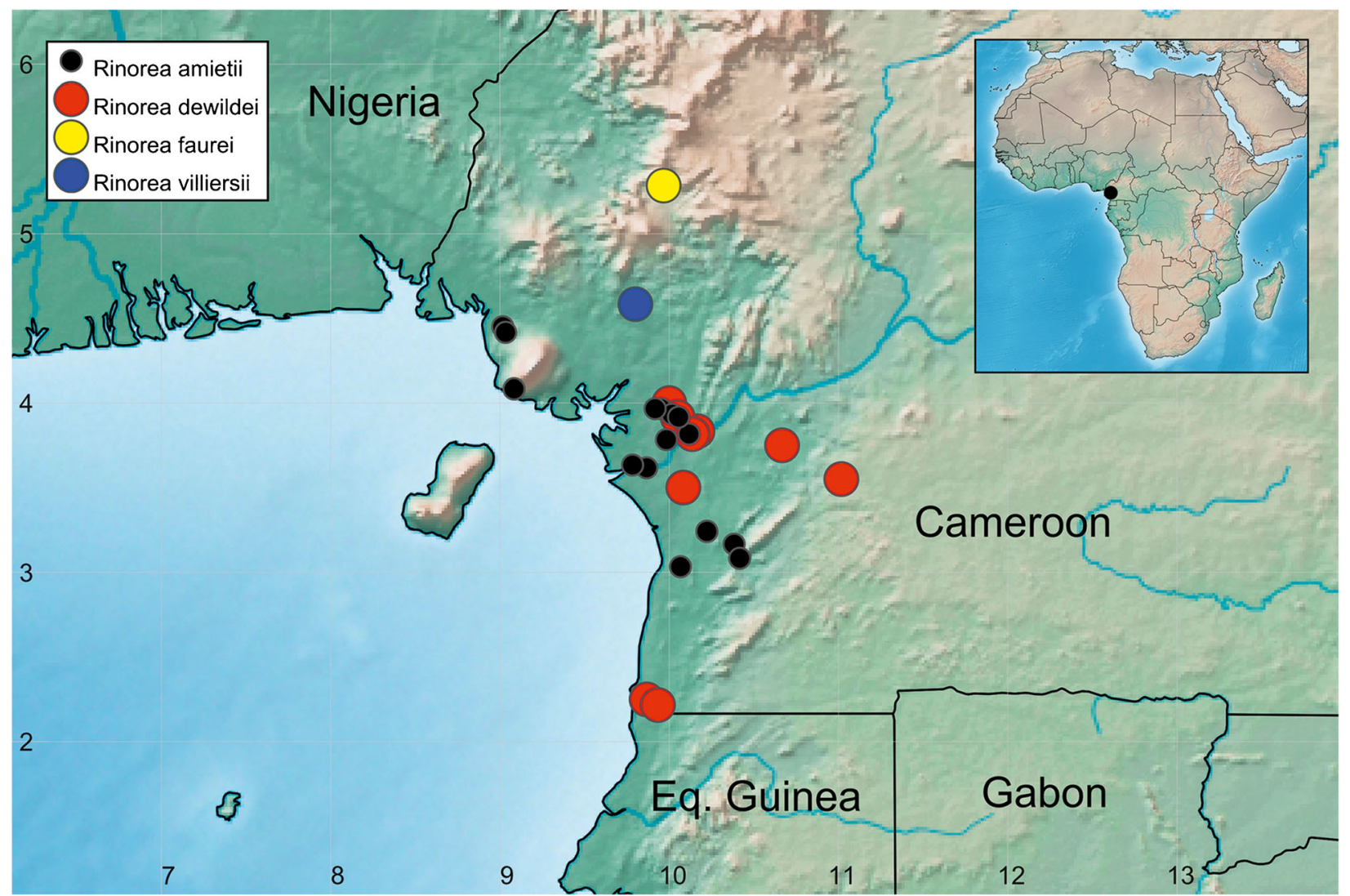

Map 1. Global distributions of Rinorea villiersii, R. amietii, R. dewildei and R. faurei. Prepared with www.simplemappr.net

the relevant nomenclatural code (Turland et al. 2018), but also to formally assess the species for their extinction risk, applying the criteria of a recognised system, of which the IUCN Red List of Threatened Species is the most widely accepted (Bachman et al. 2019). Despite rapid increases over recent years in numbers of plant species represented by assessments on the Red List, the vast majority of plant species still lack such assessments (Nic Lughadha et al. 2020).

Increasing representation of plants on the Red List is imperative but documenting threatened species in the level of detail required for inclusion on the Red List is resource intensive (Juffe-Bignoli et al. 2016) and securing the required peer-review for completed assessments to be accepted for the Red List can be slow and problematic (Bachman et al. 2019). Alternative approaches to evaluating extinction risk, including automated or semi-automated methods involving digitally available information and artificial intelligence, have been applied to plants in recent years (e.g., Darrah et al. 2017; Nic Lughadha et al. 2019; Zizka et al. 2020), often with demonstrable success in correctly predicting the threat status of species previously assessed for the Red List. However, caution is needed in considering such automated assessment approaches for adoption as conservation tools, not only for a variety of technical reasons (Walker et al. 2020) but also because they lack the power that an IUCN Red List assessment has to help change the fate of a species.

As a global standard, the IUCN Red List not only provides stable and evidence-based methods for biodiversity scientists to assess and document the extinction risk of individual species, thus facilitating comparison of the extinction risk of taxonomic groups and areas worldwide (e.g., Nic Lughadha et al. 2020; Mair et al. 2021), it also supports the safeguarding and sustainability frameworks used by businesses and their major lenders (Bennun et al. 2018; Juffe-Bignoli et al. 2016). For example, clients of the International Finance Corporation (World Bank Group) are required to use the Red List to inform project risks and to refrain from activities leading to a net reduction in populations of species assessed on the Red List as Endangered (EN) or Critically Endangered (CR), over a reasonable timescale. Species whose likely extinction has been avoided or reduced as a result of these rules include Stylochaeton pilosum Bogner, Marsdenia exellii C.Norman, Raphionacme caerulea E.A.Bruce (all EN), and Tarenna hutchinsonii Bremek. (CR) (Couch et al. 2014; Couch et al. 2019). 
National governments and leaders also recognise the importance of species assessed as threatened by the Red List, as demonstrated recently in Cameroon when, in part due to the high number of plant species on the Red List (Lovell 2020), a logging concession was revoked for the Ebo forest (Kew Science News 2020).

Thus while the Conservation Status statements included in the species treatments in the present paper suffice to highlight the threatened status of these species to the taxonomic botany community, completion and review of full assessments must follow so that they can be published on the IUCN Red List. Their assessments on the Red List will facilitate their inclusion in larger scale studies, including future global extinction risk estimates and conservation prioritisation exercises, but, most importantly, it will enable not only scientists, but also local communities, NGOs and national authorities to promote and take action to safeguard them.

Documented extinctions of plant species are increasing (Humphreys et al. 2019) and recent estimates suggest that as many as two fifths of the world's plant species are now threatened with extinction (Nic Lughadha et al. 2020). In Cameroon, Oxygyne triandra Schltr. and Afrothismia pachyantha Schltr. of South West Region, Cameroon are now known to be globally extinct (Cheek \& Williams 1999; Cheek et al. 2018a; Cheek et al. 2019). In some cases, Cameroon species appear to have become extinct even before they are known to science, such as Vepris bali Cheek (Cheek et al. 2018b).

Most of the 815 Cameroonian species in the Red Data Book for the plants of Cameroon are threatened with extinction due to habitat clearance or degradation, especially of forest for small-holder and plantation agriculture following logging (Onana \& Cheek 2011). Efforts are now being made to delimit the highest priority areas in Cameroon for plant conservation as Tropical Important Plant Areas (TIPAs) using the revised IPA criteria set out in Darbyshire et al. (2017). This is intended to help avoid the global extinction of additional endemic species such as the Rinorea species published in this paper which will be included in the future proposed TIPAs.

\section{Acknowledgements}

The first author thanks IRAD-National Herbarium of Cameroon (YA) for support in his retirement that has enabled him to continue and finalise his taxonomic research on Violaceae of Cameroon for the Flore $d u$ Cameroun. He also thanks colleagues at Wageningen for retrieving and transmitting the excellent figures that illustrate this paper, mainly drawn by J. M. (Hans) de Vries, with valuable contributions by Jean Michel Onana. He thanks Robin van Velzen for data on the molecular phylogenetic placement of taxa. This paper was completed as part of the Cameroon TIPAs (Tropical Important Plant Areas) project at RBG, Kew, which is supported by Players of Peoples Postcode Lottery. Formal Red Listing of these four species, once they are formally published, will be supported by the John S. Cohen Foundation.

Open Access This article is licensed under a Creative Commons Attribution 4.0 International License, which permits use, sharing, adaptation, distribution and reproduction in any medium or format, as long as you give appropriate credit to the original author(s) and the source, provide a link to the Creative Commons licence, and indicate if changes were made. The images or other third party material in this article are included in the article's Creative Commons licence, unless indicated otherwise in a credit line to the material. If material is not included in the article's Creative Commons licence and your intended use is not permitted by statutory regulation or exceeds the permitted use, you will need to obtain permission directly from the copyright holder. To view a copy of this licence, visit http://creativecommons.org/ licenses/by/4.0/.

\section{References}

Achoundong, G. (1996). Les Rinorea comme indicateurs des grands types forestiers du Cameroun. In: L. J. G. van der Maesen, X. M. van der Burgt \& J. M. Van Medenbach-de Rooy (eds), The Biodiversity of African Plants, pp. 536 - 544. Kluwer Academic Publishers, Dordrecht. https://doi.org/ 10.1007/978-94-009-0285-5_69

(1997). Rinorea du Cameroun, Systématique, Biologie, Ecologie, Phytogéographie. Thèse Université de Yaoundé I, Yaoundé.

(2000). Les Rinorea et l'étude des refuges forestiers en Afrique. In: M. Servant \& S. ServantVildary (eds), Dynamique à long terme des écosystèmes forestiers intertropicaux, pp. 19 - 29. Mémoire UNESCO, Paris.

(2003). Novitates Gabonenses 45. Une nouvelle espèce de Rinorea (Violaceae) du Gabon. Adansonia n.s. 25: $211-215$.

\& Bakker, F. T. (2006). Deux nouvelles espèces de Rinorea, série Ilicifoliae (Violaceae) du Cameroun. Adansonia, sér. 3, 28 (1): 129 - 136.

\& Bos, J. J. (1999). Novitates Gabonenses: 37. Espèces nouvelles de Rinorea (Violaceae) du Gabon. Adansonia 21 (1): 125 - 131.

\& (2001). Deux espèces nouvelles de Rinorea (Violaceae) du Congo et du Gabon. Adansonia 23 (1): 155 - 159. 
\& Cheek, M. (2003). Two new species of Rinorea (Violaceae) from western Cameroon. Kew Bull. 58: 957 - 964. https://doi.org/10.2307/4111209

\& (2005). Two further new species of Rinorea (Violaceae) from Cameroon. Kew Bull. 60 (4): $581-586$.

\& Onana, J. (1998). Allexis zygomorpha (Violaceae): a new species from the Littoral Forest of Cameroon. Kew Bull. 53 (4): 1009 - 1010. https://doi.org/10.2307/4118897

Amiet, J.-L. (1997). Spécialisation trophique et premières états chez les Cymothoe: implications taxonomiques (Lepidoptera, Nymphalidae). Bull. Soc. Entomol. France 102: 15 - 29.

(2000). Les premiers états des Cymothoe: Morphologie et intérêt phylogénique (Lepidoptera, Nymphalidae). Bull. Soc. Entomol. France 106: 349 - 390. \& Achoundong, G. (1996). Un exemple de speciation trophique chez les Lepidopteres: les Cymotoe camerounaises inféodées au Rinorea (Violacies) (Lepidoptera, Nymphalidae). Bull. Soc. Entomol. France 105 (5): 449 - 466.

Bachman, S. P., Field, R., Reader, T., Raimondo, D., Donaldson, J., Schatz, G. E. \& Lughadha, E. N. (2019). Progress, challenges and opportunities for Red Listing. Biol. Conservation 234: 45 - 55. https:// doi.org/10.1016/j.biocon.2019.03.002

Moat, J., Hill, A., de la Torre, J. \& Scott, B. (2011). Supporting Red List threat assessments with GeoCAT: geospatial conservation assessment tool. ZooKeys. 150: 117 - 126. https://doi.org/10.3897/ zookeys.150.2109

Bakker, F. T., van Gemerden, B. S. \& Achoundong, G. (2006). Molecular systematics of African Rinorea Aublet. (Violaceae). In: S. A. Ghazanfar \& H. J. Beentje (eds), Taxonomy and ecology of African plants, their conservation and sustainable use, pp. 33 - 44 . Royal Botanic Gardens, Kew.

Bennun, L., Regan, E. C., Bird, J., van Bochove, J. W., Katariya, V., Livingstone, S., Mitchell, R., Savy, C., Starkey, M., Temple, H. \& Pilgrim, J. D. (2018). The value of the IUCN Red List for business decisionmaking. Conservation Lett. 11 (1): p.e12353. https:/ / doi.org/10.1111/conl.12353

Brandt, M. (1914). Übersicht über die afrikanischen Arten der Gattung Rinorea Aubl. Bot. Jahrb. Syst. 51: $405-418$.

Cable, S. \& Cheek, M. (1998). The Plants of Mt Cameroon, a Conservation Checklist. Royal Botanic Gardens, Kew.

Chapman, J. \& Chapman, H. (2001). The Forests of Taraba and Adamawa States, Nigeria an Ecological Account and Plant Species Checklist. University of Canterbury, Christchurch.

Cheek, M. (2007). Afrothismia amietii (Burmanniaceae), a new species from Cameroon. Kew Bull. 61: 605 607. http://www.jstor.org/stable/20443306
(2017). Rinorea simoneae. The IUCN Red List of Threatened Species 2017: e.T110087540A110087542. https://doi.org/10.2305/IUCN.UK.20173.RLTS.T110087540A110087542.en.

, Etuge, M. \& Williams, S. (2019). Afrothismia kupensis sp. nov. (Thismiaceae), Critically Endangered, with observations on its pollination and notes on the endemics of Mt Kupe, Cameroon. Blumea 64 (1): 158 - 164. https://doi.org/10.3767/ blumea.2019.64.02.06

, Gosline, G. \& Onana, J-M. (2018b). Vepris bali (Rutaceae), a new critically endangered (possibly extinct) cloud forest tree species from Bali Ngemba, Cameroon. Willdenowia 48: 285 - 292. doi: https://doi.org/10.3372/wi.48.48207

, Harvey Y. \& Onana J-M. (2010). The Plants of Dom, Bamenda Highlands, Cameroon, A Conservation Checklist. Royal Botanic Gardens, Kew.

\& (2011). The Plants of Mefou

Proposed National Park, Yaoundé, Cameroon, A Conservation Checklist. Royal Botanic Gardens, Kew.

Nic Lughadha, E., Kirk, P., Lindon, H., Carretero, J., Looney, B., Douglas, B., Haelewaters, D., Gaya, E., Llewellyn, T., Ainsworth, M., Gafforov, Y., Hyde, K., Crous, P., Hughes, M., Walker, B. E., Forzza, R. C., Wong, K. M. \& Niskanen, T. (2020). New scientific discoveries: plants and fungi. Plants, People Planet 2: 371 - 388. https://doi.org/10.1002/ ppp3.10148

, Onana, J-M. \& Pollard, B. J. (2000). The Plants of Mount Oku and the Ijim Ridge, Cameroon, a Conservation Checklist. Kew, Royal Botanic Gardens.

, Pollard, B. J., Darbyshire, I., Onana, J-M. \& Wild, C. (2004). The Plants of Kupe, Mwanenguba and the Bakossi Mountains, Cameroon: A Conservation Checklist. Royal Botanic Gardens, Kew.

, Tsukaya, H., Rudall, P. J. \& Suetsugu, K. (2018a). Taxonomic monograph of Oxygyne (Thismiaceae), rare achlorophyllous mycoheterotrophs with strongly disjunct distribution. PeerJ, 6, e4828. https://doi.org/ $10.7717 /$ peerj. 4828

\& Williams, S. (1999). A Review of African Saprophytic Flowering Plants. In: J. R. Timberlake \& S. Kativu (eds), African Plants. Biodiversity, Taxonomy $\mathcal{E}$ Uses. Proceedings of the 15th AETFAT Congress at Harare, Zimbabwe, pp. 39 - 49. Royal Botanic Gardens, Kew.

Couch, C., Molmou, D., Camara, B., Cheek, M., Merklinger, F., Davies, L., Harvey, Y., Lopez Poveda, L. \& Redstone, S. (2014). Conservation of threatened Guinean inselberg species. In: XXth AETFAT Congress, South Africa, 2014 [Abstract 96]. Scripta Bot. Belg. (52: 96).

, Cheek, M., Haba, P., Molmou, D., Williams, J., Magassouba, S., Doumbouya, S. \& Diallo, M. Y. (2019). Threatened Habitats and Tropical Impor- 
tant Plant Areas (TIPAs) of Guinea, West Africa. Royal Botanic Gardens, Kew.

Darbyshire, I. \& Cheek, M. (2004a). Rinorea fausteana. The IUCN Red List of Threatened Species 2004: e.T46185A11034817. https://doi.org/10.2305/ IUCN.UK.2004.RLTS.T46185A11034817.en.

\& (2004b). Rinorea thomasii. The IUCN Red List of Threatened Species 2004: e.T46186A11034916. https:/ / doi.org/10.2305/IUCN.UK.2004.RLTS. T46186A11034916.en.

, Anderson, S., Asatryan, A., Byfield, A., Cheek, M., Clubbe, C., Ghrabi, Z., Harris, T., Heatubun, C. D., Kalema, J., Magassouba, S., McCarthy, B., Milliken, W., Montmollin, B. de, Nic Lughadha, E., Onana, J. M., Saıdou, D., Sarbu, A., Shrestha, K. \& Radford, E. A. (2017). Important Plant Areas: revised selection criteria for a global approach to plant conservation. Biodivers. Conservation 26: 1767 1800. https://doi.org/10.1007/s10531-017-1336-6

Darrah, S. E., Bland, L. M., Bachman, S. P., Clubbe, C. P. \& Trias-Blasi, A. (2017). Using coarse-scale species distribution data to predict extinction risk in plants. Diversity and Distributions 23: 435 - 447. https://doi.org/10.1111/ddi.12532

Harvey, Y., Pollard, B. J., Darbyshire, I., Onana, J-M. \& Cheek, M. (2004). The Plants of Bali Ngemba Forest Reserve, Cameroon. A Conservation Checklist. Royal Botanic Gardens, Kew.

, Tchiengue, B. \& Cheek, M. (2010). The plants of the Lebialem Highlands, a conservation checklist. Royal Botanic Gardens, Kew.

Humphreys, A. M., Govaerts, R., Ficinski, S. Z., Lughadha, E. N. \& Vorontsova, M. S. (2019). Global dataset shows geography and life form predict modern plant extinction and rediscovery. Nature Ecol. Evol. 3.7: 1043 - 1047. https://doi.org/ $10.1038 / \mathrm{s} 41559-019-0906-2$

IPNI (continuously updated). The International Plant Names Index. Available from: http://ipni.org/ [Accessed March 2021].

IUCN (2012). IUCN red list categories: Version 3.1. IUCN Species Survival Commission, Gland and Cambridge.

Juffe-Bignoli, D., Brooks, T. M., Butchart, S. H., Jenkins, R. B., Boe, K., Hoffmann, M., Angulo, A., Bachman, S., Böhm, M., Brummitt, N. \& Carpenter, K. E. (2016). Assessing the cost of global biodiversity and conservation knowledge. PLoS One 11(8) https://doi.org/10.1371/ journal.pone.0160640

Kew Science News (2020). Ebo Forest Logging Plans Suspended. https://www.kew.org/read-and-watch/ ebo-forest-logging-suspended [Accessed 5 May 2021].

Lovell, R. (2020). Timber! The threat to Cameroon's Ebo Forest. https://www.kew.org/read-and-watch/ ebo-forest-cameroon [Accessed 5 May 2021].

Mair, L., Bennun, L. A., Brooks, T. M., Butchart, S. H., Bolam, F. C., Burgess, N. D., Ekstrom, J. M., Milner-
Gulland, E. J., Hoffmann, M., Ma, K. \& Macfarlane, N. B. (2021). A metric for spatially explicit contributions to science-based species targets. Nature Ecol. Evol. 5 : 836 - 844. https:/ /doi.org/10.1038/s41559-021-01432-0

Maisels, F. M., Cheek, M. \& Wild, C. (2000). Rare plants on Mount Oku summit, Cameroon. Oryx 34: 136 140. https://doi.org/10.1017/s0030605300031057.

Nic Lughadha, E., Walker, B. E., Canteiro, C., Chadburn, H., Davis, A. P., Hargreaves, S., Lucas, E. J., Schuiteman, A., Williams, E., Bachman, S. P. \& Baines, D. (2019). The use and misuse of herbarium specimens in evaluating plant extinction risks. Philos. Trans., Ser. B, 374 (1763), p.20170402. https://doi.org/10.1098/rstb.2017.0402

, Bachman, S. P., Leão, T. C., Forest, F., Halley, J. M., Moat, J., Acedo, C., Bacon, K. L., Brewer, R. F., Gâteblé, G. \& Gonçalves, S. C. (2020). Extinction risk and threats to plants and fungi. Plants, People, Planet 2 (5): 389 - 408. https://nph.onlinelibrary.wiley.com/ doi/10.1002/ppp3.10146

Onana, J.-M. (2011). The vascular plants of Cameroon, a taxonomic checklist with IUCN Assessments. Royal Botanic Gardens, Kew.

\& Cheek, M. (2011). Red data book of the flowering plants of Cameroon, IUCN global assessments. Royal Botanic Gardens, Kew.

Plants of the World Online (continuously updated). Facilitated by the Royal Botanic Gardens, Kew. http:/ / www.plants of theworldonline.org/ ?f=accepted_names\&q=Vepris (downloaded 1 May 2021)

Sosef, M. S. M., Wieringa, J. J., Jongkind, C. C. H., Achoundong, G., Azizet Issembé, Y., Bedigian, D., Van Den Berg, R. G., Breteler, F. J., Cheek, M. \& Degreef, J. (2006). Checklist of Gabonese Vascular Plants. Scripta Bot. Belg. 35. National Botanic Garden of Belgium.

Thiers, B. (continuously updated). Index Herbariorum: A global directory of public herbaria and associated staff. New York Botanical Garden's Virtual Herbarium. Available from: http://sweetgum.nybg.org/ih/ [Accessed March 2021].

Turland, N. J., Wiersema, J. H., Barrie, F. R., Greuter, W., Hawksworth, D. L., Herendeen, P. S., Knapp, S., Kusber, W.-H., Li, D.-Z., Marhold, K., May, T. W., McNeill, J., Monro, A. M., Prado, J., Price, M. J. \& Smith, G. F. (eds) (2018). International Code of Nomenclature for algae, fungi, and plants (Shenzhen Code) adopted by the Nineteenth International Botanical Congress Shenzhen, China, July 2017. Regnum Veg. 159. Koeltz Botanical Books, Glashütten. https://doi.org/10.12705/ Code.2018

van Velzen, R. \& Wieringa, J. J. (2014). Rinorea calcicola (Violaceae), an endangered new species from south-eastern Gabon. Phytotaxa 167 (3): 267 - 275. https://doi.org/10.11646/phytotaxa.167.3.5 
Wahlert, G. A., Sosef, M. S., Onstein, R. E. \& Bakker, F. T. (2015). Phylogenetics of African Rinorea (Violaceae): Elucidating Infrageneric Relationships using Plastid and Nuclear DNA Sequences. Syst. Bot. 40 (1): 174 - 184. https:// doi.org/10.1600/036364415X686486

Wahlert, G. A. (2010). Phylogeny, biogeography, and a taxonomic revision of Rinorea (Violaceae) from Madagascar and the Comoro Islands. Ph.D. Thesis. Ohio University, Athens.

\& Ballard, H. E. (2012). A phylogeny of Rinorea (Violaceae) inferred from plastid DNA sequences with an emphasis on the African and Malagasy species. Syst. Bot. 37: 964 - 973. https://doi.org/ $10.1600 / 036364412 X 656392$
Walker, B. E., Leão, T. C., Bachman, S. P., Bolam, F. C. \& Nic Lughadha, E. (2020). Caution needed when predicting species threat status for conservation prioritization on a global scale. Frontiers Pl. Sci. 11: 520. https://doi.org/10.3389/fpls.2020.00520

Zizka, A., Silvestro, D., Vitt, P. \& Knight, T. M. (2020). Automated conservation assessment of the orchid family with deep learning. Conservation Biol. https://doi.org/10.1111/cobi.13616

\section{Publisher's Note}

Springer Nature remains neutral with regard to jurisdictional claims in published maps and institutional affiliations. 